Article

\title{
Institutional Reforms and Their Impact on Economic Growth and Investment in Developing Countries
}

\author{
Jin Zhao ${ }^{1}$, Ghulam Rasool Madni ${ }^{2, *(D)}$, Muhammad Awais Anwar ${ }^{2}$ and Syeda Masooma Zahra ${ }^{3}$ \\ 1 School of Finance, Shanghai Lixin University of Accounting and Finance, Shanghai 201209, China; \\ sh9621@hotmail.com \\ 2 Department of Economics and Business Administration, Lower Mall Campus, University of Education, \\ Lahore 54000, Pakistan; awais.anwar@ue.edu.pk \\ 3 MPhil Graduate from Department of Economics, The University of Lahore, Lahore 54590, Pakistan; \\ smzahra97@gmail.com \\ * Correspondence: ghulam.rasool@ue.edu.pk
}

Citation: Zhao, J.; Madni, G.R.;

Anwar, M.A.; Zahra, S.M.

Institutional Reforms and Their Impact on Economic Growth and Investment in Developing Countries. Sustainability 2021, 13, 4941.

https://doi.org/10.3390/su13094941

Academic Editor: Bruce Morley

Received: 24 March 2021

Accepted: 22 April 2021

Published: 28 April 2021

Publisher's Note: MDPI stays neutral with regard to jurisdictional claims in published maps and institutional affiliations.

Copyright: (C) 2021 by the authors. Licensee MDPI, Basel, Switzerland. This article is an open access article distributed under the terms and conditions of the Creative Commons Attribution (CC BY) license (https:/ / creativecommons.org/licenses/by/ $4.0 /)$.

\begin{abstract}
It is widely accepted that the economic and social system may be more efficient by reforming institutions. Institutional reforms are attempts to change the rules affecting human interactions and these reforms are fundamental for development and economic prosperity. The reforms can be divided into two categories; political and economic institutional reforms. It is need of the hour to determine the category of reform that is more suitable for developing countries. Moreover, a vast literature describes the impact of institutional reforms but little focused on exploring their impacts on macroeconomic activities. So, this study is an effort to determine the impact of institutional reforms on macroeconomic variables by considering the panel data of 122 developing countries covering the time span from 1996 to 2019. The study applied treatment analysis using the difference-in-differences technique to gauge the effects of reforms. Besides, it will be interesting to know the causes triggering the institutional reforms in developing countries. The findings of the study reveal that economic reforms are more important as compared with political reforms to grow the economies. The countries focusing on political reforms are not able to overcome the economic crisis. Moreover, both types of reforms do not cause each other in these countries.
\end{abstract}

Keywords: political institutional reforms; economic institutional reforms; difference in differences; economic growth; investment

\section{Introduction}

Institutions affect the economy through the creation of an environment necessary for prosperity and development. When a country makes progress towards development, the needs also develop, so there is a requirement to make institutional reforms [1]. The lags in implementing the institutional reforms result in a slower development process having far-reaching macro-economic consequences [2].

Institutional reforms are attempts to change the rules affecting human interactions. It is a structure of actions, ways of execution, crisis management, and main interaction principles with other entities [3]. The crises from 1929 to 1933 were treated by Roosevelt's reforms while Reagan's reforms were a response against the stagnation of the 1970s [4]. The Erhard's reforms were changes in economic policy to improve and modernize the economic system after the war to restore the economy. To respond to the new paradigm, countries have adopted a variety of institutional reforms [5].

Institutional reforms gained a significant position in literature, as well as in sight of policymakers in the past few years. The international organizations like the International Monetary Fund, World Bank, etc., have a great concern now to institutional reforms for donations and assistance [6,7]. Many studies have argued that income differences across countries are due to the quality of institutions [1-8]. Institutional reforms and their impact 
on economies has gained the attention of policymakers, international organizations, and researchers but many questions are unsettled yet regarding the effectiveness of political and economic institutional reforms on economic outcomes; the relationship between economic and political institutional reforms; sequence of reforms for a country $[9,10]$.

There are two broad sets of literature in new institutional economics; effects of institutional quality on economic outcomes [2,3] and effects of institutional reforms on macroeconomic indicators [5-7]. The focus of the first set is to find the effects of economic institutions on countries $[11,12]$ while the second describes the impact of political institutions (study 15 discussed brief literature on the topic). Moreover, some studies $[13,14]$ examined the impact of both types of institutions on economic variables. In the same way, the effectiveness of political and economic institutional reforms is also discussed by numerous studies but their impact on macroeconomic indicators is hardly discussed [15-18].

The economic institutions are rules governing the laws, policies, and regulating the relations of economic agents in markets [19]. These rules define the extent of restrictions on economic agents to make transactions. These institutions provide incentive structure and mechanism to main economic agents in a society; influencing the level of investments in physical and human capital, technology, and production [20-22]. The transaction cost is minimized through economic institutions. The examples of economic institutions are laws concerned with property rights, credit arrangements, regulatory quality, and policies affecting access to means of production, as well as consumption [23]. Table 1 depicts the economic institutional reforms over time in 9 selected countries with respect to the index of economic freedom 2020. The index of economic freedom 2020 defines economic freedom as "Economic freedom is the fundamental right of every human to control his or her own labor and property. In an economically free society, individuals are free to work, produce, consume, and invest in any way they please. In economically free societies, governments allow labor, capital, and goods to move freely, and refrain from coercion or constraint of liberty beyond the extent necessary to protect and maintain liberty itself."

Table 1. Top Economically Unfree Countries (Economic Institutional Reforms Overtime).

\begin{tabular}{|c|c|c|c|c|c|c|c|c|}
\hline \multirow{2}{*}{$\begin{array}{c}\text { Unfree Countries } \\
\text { Average of Ten Years }\end{array}$} & \multicolumn{2}{|c|}{ Property Rights } & \multicolumn{2}{|c|}{ Business Freedom } & \multicolumn{2}{|c|}{ Labor Freedom } & \multicolumn{2}{|c|}{ Investment Freedom } \\
\hline & $2011-2020$ & 2000-2010 & $2011-2020$ & $2000-2010$ & 2011-2010 & $2000-2010$ & 2011-2010 & 2000-2010 \\
\hline Uganda & 33.6 & 39.09 & 45.6 & 60.05 & 85.7 & 60.0 & 55.5 & 49.1 \\
\hline Pakistan & 33.8 & 30 & 63.5 & 66.7 & 43.5 & 56.0 & 47.5 & 56.9 \\
\hline Nepal & 33.6 & 32.0 & 61.1 & 57.6 & 46.2 & 46.3 & 8 & 27.7 \\
\hline Egypt & 32.3 & 45.8 & 65.4 & 54.6 & 50.7 & 60.5 & 56.5 & 50 \\
\hline India & 53.7 & 50 & 47.02 & 52 & 55.1 & 62.2 & 36.8 & 41.3 \\
\hline Sri Lanka & 41.9 & 49.1 & 74.2 & 70.4 & 59.4 & 69.6 & 36 & 38.6 \\
\hline South Africa & 55.2 & 50 & 69.34 & 72.3 & 58.12 & 72.38 & 76.01 & 69.72 \\
\hline North Korea & 14.3 & 5.95 & 2.5 & 21.8 & 2.5 & 0 & 0 & 10 \\
\hline Bangladesh & 26.4 & 27.5 & 59.5 & 48.7 & 61.19 & 58.7 & 50 & 38.6 \\
\hline
\end{tabular}

Source: Heritage Foundation 2020; the variables range from 0 to 100 . Higher numbers show high positions in that category.

Countries with efficient economic structure provide a suitable environment and incentives to their people so they grow faster as compared with states having extraordinary powers. The top economically free countries like Singapore, Hong Kong, and New Zealand are providing business freedom, investment freedom, and secure property rights for the efficient functioning of markets that raise the trust level, reduce uncertainty, and create an immense amount of revenue for the economy. In contrast, the mostly unfree states like Pakistan, India, Bangladesh, and North Korea have poor economic policies and lack of attention towards economic stability. The economic and political agents focus on political stability rather than economic which makes them unable to grow consistently [24,25].

On the other hand, political institutions deal with how to organize the political system, how power and authority is derived, legitimized, redistributed, exercised, and controlled [26]. Different political systems were experienced by states like democracy, dictatorship, communism, and monarchy but the point of discussion is how they evaluated the accountability and credibility of ruling political agents. From the historical perspective, 
many societies achieved economic growth and development from the active influence of government [9]. A government with unnecessary spending, unstable democracy, and other disorders cannot achieve the desired level of economic growth and development. It is evident that democracy regulates the negative effects on growth $[22,24,25]$. Every economy providing effective law and order conditions gained more economic affluence and development. On the other hand, economies having an inefficient environment for economic agents, face the problems of lower levels of development and un-sustained growth [12].

It is widely agreed that institutional reforms are a key factor for the development of nations but which institutional reforms are more effective for a country is a point of controversy [27]. For the last few years, the debate of institutional change is at the main front of literature. Besides, economies want to make political forces stronger ignoring the significance of economic forces. Nowadays, economies are unable to make effective policy preferences regarding their democratic institutions and economic institutions, which should reform first to compete with the international markets. Moreover, implementation of both types of reforms is not an easy task for developing countries so this study provides an answer to which type of institutions should be reformed first for better macro and microeconomic performance. These issues are not addressed in earlier literature on the topic. It is hypothesized that economic institutional reforms are more necessary as compared with political reforms. Thus, the main objective of this paper is to investigate the impact of each kind of institutional reform (political and economic) on economic growth and investment in developing countries. For the purpose, data are collected for 122 developing countries over the time period of 1996-2019 and the difference-in-difference regression technique is applied to find the answer to the above questions. It will help the policymakers to move towards effective decisions for more sustained growth and cohesive social factors.

\section{Literature Review}

Barro [27] extended the literature by measuring institutional quality through several variables for 98 countries covering the period of 1960-1985. The impact of these variables on economic growth was observed by the study. The findings through econometric analysis reveal the positive and significant relationship between economic growth and institutional quality.

Caldwell [28] highlighted theoretical perspectives of parliamentary and presidential systems (democratic institutions) affecting bureaucracy and market systems. It is explained that democratic institutions generate all structural programs like a framework for leadership and bureaucracy, and structural policies that automatically create a government. The author provides the solution to state-level problems by analyzing the credibility of political agents, and developed extremely appealing structural policies and strategies. In the parliamentary system, if the power is solely controlled by the parliamentary agents, they become unable to secure political interests. They have no other way to solve the state's problems and never try to develop structural policies and strategies. It is concluded that different political institutions arrange structural development for political agents. So, this allows institutional theories to find out their way.

Knack and Keefer [29] determined the relationship among institutional environment, economic growth, and investment by using the variables of government type and bureaucracy. They followed Barro [27] by using the same empirical technique and period, which produced almost the same findings. It is highlighted that institutions promoting the protection of property rights are necessary for economic growth and investment. They found that property rights not only affect the volume of investment but enhance the efficiency of inputs also.

Kaufmann et al. [30] determined the causal relationship between institutions and economic growth considering the data of more than 150 states. The authors collected 300 governance indicators from different sources and applied the ordinary least square method for empirical analysis. They unraveled their findings with the extensive theoretical justification that institutional reforms boost economic growth. Interestingly, this 
study is widely used to prove the relationship between institutional quality and economic development in an improved form.

From the historical perspective, it is explained that all European colonies tried to maintain their economic interests during conflicts between England and France [31]. It is a question of concern how economies like the USA and Canada became economically so strong as compared with other countries. Economies other than America and Canada were established earlier, but what are the strategies adopted by the USA and Canada to raise and sustain their per capita income. With the data of per capita GDP, the author addressed these queries from a historical perspective. It is concluded that the continuous change in society, wealth, political power, institutional quality, reforms, and economic rules assisted these countries to sustain their development.

The inaccurate macroeconomic policies ended up with high inflation, unstable exchange rate, high budget deficit, and low level of economic growth after the Second World War [32]. It is highlighted that poor and inconsistent economic policies weaken the institutional structure and encourage the political agents for inefficient property rights; consequently, corruption increases, and the political system becomes unstable. Moreover, there are many economies with better institutional policies and strategies to overcome the economic crisis so instability does not exist there.

Siourounis [33] identified the short-run and long-run impact of political democratic transition and reforms on economic growth. The study conducted the panel data analysis and found that democratization raises the real annual per capita income by $1 \%$. During the period of transition, growth falls considerably, and then again, after the period of change, it stabilizes even at a higher rate. It is concluded that all those countries could excel in their economic growth rate where well-functioning and efficient institutions prevail.

The impact of institutional reforms on the economic growth in transition economies is explored based on theoretical and empirical evidence [34]. The authors estimated the secondary data of all European Union countries for the period of 1996 to 2012 by applying Arellano-Bond dynamic panel analysis. The findings of the study reveal that there is a positive correlation between institutional reforms and economic growth. The transition economies are different for their informal norms and formal institutional structure, but these institutions and institutional reforms have a positive impact even in the short run. However, lack of improvement in institutional quality in some countries is a source to lower the GDP per capita over time. Most importantly, the Republic of Croatia is required to change its model of economic growth and its consumption growth patterns.

The long-run impact of institutional quality on the financial sector in 15 emerging and growth leading economies (EAGLES) is investigated considering the period from 1984 to 2017 by applying simple ordinary least square [35]. According to the empirical results, there is a positive impact of institutional quality on financial development and this financial development leads to improve economic growth in these countries. It is suggested that the policymakers have to consider the importance of institutional quality to sustain the development process. The study also analyzed that weak institutions lower the control over corruption and do not have proper accountability promoting political instability. In addition, low-income countries are more unstable for their institutional quality and require serious attention to improve their governance and institutional reforms for the betterment of financial development.

The above findings of different studies reveal the significance of institutional quality and institutional reforms. Many studies explored the effects of formal and informal institutions by shedding light on the importance of property rights, government effectiveness, bureaucracy, political system, and effects on the financial sector. For achieving high economic growth and sustainable development process, the role of economic and political institutional reforms cannot be negated. The earlier literature laid down the foundations of a strong relationship between institutions and macroeconomic indicators. It is evident that institutional reforms in any country are a source to improve the efficiency and productivity of the economy. Strong and efficient institutions restore the trust of people and investors 
in the state. The investors prefer to invest in the country having more efficient institutions due to less bribery and corruption. When the institutional structure is supportive for people and investors then people feel respected. The developing countries have the issue of weak and inefficient institutional structure for their poor performance. Now it is a great concern of every country to improve the quality of institutions for wellbeing and economic growth so every country is reforming its institutions. Some countries are focusing on political while others are prioritizing the economic institutions to be reformed. There is hardly any study describing the sequence of reforms that may be more beneficial, especially for developing economies. As implementation of both types of reforms is not an easy task for developing countries so this study is an attempt to explain which type of institutions should reform first for better macro and microeconomic performance in a panel of 122 developing countries. This study is an attempt to answer the suitable sequence of reforms in developing countries to boost and sustain their economic growth.

\section{Methodology}

When a new policy is applied, the effects of policy are needed to determine. Differencein-differences (DID) is a way to measure the impact of new policies [36]. In this approach, outcomes are examined for two separate groups in two different time periods. By using difference in difference, we get the outcomes of the public exposed to interference (treated group) and people without exposition of interference (control group), as well as both pre and after the interference [37]. The pre-experienced group is treated as "control" while the post-experienced group is exposed as "treated". This paper applied the difference in differences estimation approach which is appropriate to combine the pre and post reform consequences. This methodology allows us to analyze time series and cross-sectional changes in data [38]. It estimates the effect of a specific treatment group, such as implementation of various programs on a large scale. This technique defines the experimental design that allows to use the longitudinal data in two groups (treated and control) to have proper counterfactual through estimating the causal effects $[39,40]$. If the same unit in a group is presented in each time period, then the mean gain of the treatment group is subtracted by the average gain of the control group to remove biases. This study examines the effects of institutional reforms on economic variables for panel data so equation becomes as:

$$
y_{i t}=\beta_{i}+\beta_{t}+\beta \operatorname{Ref}_{i t}+\beta_{1} X_{i t}+p_{i t}
$$

where $y$ is economic outcome, $\beta_{i}$ is time invariant impact for individual $i, \beta_{t}$ shows the time impact common for all in time period $t$, Ref is reforms in political and economic institutions, $X$ represents control variables and $p_{i t}$ is error varying with respect to time which is individually and independently distributed; and independently of all $\beta_{i}$ and $\beta_{t}$ individuals. For estimations of $\beta$, some special technique is required because $\beta_{i}$ and $\beta_{t}$ have relation to institutional reforms in many ways. In this way, Equation (1) with control variable becomes, where INF shows the inflation:

$$
y_{i t}=\beta_{i}+\beta_{t}+\beta \operatorname{Ref}_{i t}+\beta_{1} I N F_{i t}+p_{i t}
$$

If $\beta_{i}$ and $\beta_{t}$ have dependency on institutional reforms, then its estimation can be carried out by taking the first difference so Equation (2) can be written as:

$$
\Delta_{t} y_{i t}=\Delta_{t} \beta_{t}+\beta \Delta_{t} \operatorname{Ref}_{i t}+\beta_{1} \Delta_{t} I N F_{i t}+\Delta_{t} \varepsilon_{i t}
$$

where $\Delta_{t}$ is the difference of individual observations across time and $\Delta_{t} \beta_{t}$ is the difference in common time periods. However, there are two periods in the model; pre reforms and post reforms period. Difference in differences estimators take the differences between two groups such that:

$$
B=\left\{E\left(y_{i 1}{ }^{t} l \operatorname{Ref}_{i 1}\right)-E\left(y_{i 1}{ }^{t} l \operatorname{Re} f_{i 0}\right)\right\}-\left\{E\left(y_{i 0}{ }^{c} l \operatorname{Ref}_{i 1}\right)-E\left(y_{i 0}{ }^{c} l \operatorname{Re} f_{i 0}\right)\right\}
$$


Superscript $t$ and $c$ in Equation (4) represent the treated and control groups, respectively, $E\left(y_{i 1}{ }^{t} l \operatorname{Re} f_{i 1}\right)$ is expected outcome of countries after reforms while $E\left(y_{i 1}{ }^{t} l \operatorname{Re} f_{i 0}\right)$ is outcome of the same group before reforms. In the same way, $E\left(y_{i 0}{ }^{c} l R e f_{i 1}\right)$ are outcomes of the control group after reforms in the treated group and $E\left(y_{i 0}{ }^{c} l R e f_{i 0}\right)$ is outcome of the control group before the reforms. According to Kilish [40], two structural assumptions are mandatory for difference in difference estimation. One is the common time effect across the control and treated groups while the other is the stable composition of both groups before and after reforms. Usually, these assumptions are violated so there are many ways to reduce the possibilities of violation of these assumptions; "First, include in the control variables dummies to capture the characteristics that make countries different. The second suggestion is to include in the control group both countries that have not experienced reform at all and countries that have experienced reform before the beginning of the sample period" [17]. This study included all those countries in the control group that have strong or weak institutional quality and never faced major changes.

The difference in difference method has many advantages, specifically in showing the effects of reforms or policy implementations [40]. It is a micro-economic technique, having potential to handle various typical endogeneity problems while making a comparison of two heterogeneous individuals. It helps in measuring the treatment effect from the control and treated group over time. This technique allows us to estimate within the country variations, as well as the variations outside the country [41]. It also helps to analyze the comparison of the treated group before and after reforms with economic consequences of the control group.

\section{Data and Their Sources}

Institutions are categorized into main two types: political and economic institutions [25]. Economic reforms are considered as large and comprehensive changes to improve regulatory quality, reducing corruption, strengthening corporate governance, rendering fiscal and monetary institutions' independence, protecting property rights, and enhancing the independence of the judiciary; so the majority of people can participate in decisions making and economic activities. The economic freedom index is used to measure the economic institutional reforms sourced from "The Heritage Foundation". According to Heritage Foundation, "The economic freedom is based on twelve qualitative and quantitative variables divided into 4 categories of economic freedom; regulatory efficiency (labor freedom, monetary freedom, business freedom), rule of law (judicial effectiveness, government integrity, property rights), government size (fiscal health, tax burden, government spending), and open markets (investment freedom, trade freedom, financial freedom)."

Political institutions are considered as the "political rules of the game" describing political decision making and the political process along with citizens' ability to keep intact with political leaders. The political reforms are large changes in the political environment associated with how political power is exercised and constituted. The variable of political institutions is measured from the POLITY IV dataset having a spectrum of 21-point scale ranging from -10 to +10 . The extreme negative value shows the hereditary monarchy while the extreme positive value represents consolidated democracy.

The criteria for economic and political institutional reforms are taken from [17,28]. According to these studies, economic institutional reforms are considered through backward and forward-moving averages. The economic reforms are considered in those countries where the forward-moving average is greater than the backward average by at least 12 points. The reforms are divided into two heads; big and small reforms. If the forwardmoving average is greater by at least 2 points, then it is considered as small reforms but if it is greater than by at least 4 points then it is considered as big reforms. The political institution's reforms are considered when a country crosses the Polity Scores above zero because zero value shows the end of autocracy [40]. So the non-negative value of a country is considered as a treated group while zero value is treated as a control group. The description of other variables is given in Table 2. 
Table 2. List of Variables and their Description.

\begin{tabular}{cr}
\hline Variable & Description \\
\hline ERef & 1 if economic institutions reforms take place from the year otherwise 0 \\
BERef & 1 if big economic institutions reforms take place from the year otherwise 0 \\
SERef & 1 if small economic institutions reforms take place from the year otherwise 0 \\
PRef & 1 if political institutions reforms take place from the year otherwise 0 \\
THPRE & 1 if three years preceding economic reforms otherwise 0 \\
THPRP & 1 if three years preceding political reforms otherwise 0 \\
THPSE & 1 if economic reforms start in the year and followed by three years otherwise 0 \\
THPSP & 1 if political reforms start in the year and followed by three years otherwise 0 \\
FRBYP & 1 if political reforms are in the $4^{\text {th }}$ year and beyond otherwise 0 \\
TREC & 1 if country treats only economic reforms otherwise 0 \\
TRPL & 1 if country treats only political reforms otherwise 0 \\
ECPL & 1 if country treats economic reforms before political reforms otherwise 0 \\
PLEC & 1 if country treats political reforms before economic reforms otherwise 0 \\
\hline
\end{tabular}

The data of economic growth, investment, and inflation is obtained from world development indicators. The data are collected from 1996 to 2019 for the lower and middle income countries categorized by the World Bank in the year 2019-2020. The sample is selected due to constraints in availability of data. All these countries are developing and have similarity in their institutional structure. The data of economic growth and investment are drawn from the World Bank.

\section{Empirical Findings and Discussion}

The difference-in-differences approach is used to find the empirical relationship among considered variables and findings are reported in the following Tables 3-5.

Table 3. Impact of Economic Reforms on Growth and Investment.

\begin{tabular}{|c|c|c|c|c|c|c|}
\hline \multirow[b]{2}{*}{ Variable } & \multicolumn{3}{|c|}{ Economic Growth } & \multicolumn{3}{|c|}{ Investment } \\
\hline & Model-I & Model-II & Model-III & Model-IV & Model-V & Model-VI \\
\hline $\mathrm{C}$ & $\begin{array}{l}0.541 \\
(3.84)\end{array}$ & $\begin{array}{c}-8.382^{* * *} \\
(2.814)\end{array}$ & $\begin{array}{c}-11.47^{* * *} \\
(5.413)\end{array}$ & $\begin{array}{c}-32.49 \\
(89.4)\end{array}$ & $\begin{array}{l}-94.79 \\
(198.2)\end{array}$ & $\begin{array}{l}-351.3 \\
(258.4)\end{array}$ \\
\hline BERef & $\begin{array}{c}0.247^{* * *} \\
(0.046)\end{array}$ & & & $\begin{array}{l}1.37^{* * *} \\
(0.754)\end{array}$ & & \\
\hline SERef & & $\begin{array}{c}0.284^{* *} \\
(0.065)\end{array}$ & & & $\begin{array}{c}0.277^{* * *} \\
(0.027)\end{array}$ & \\
\hline THPRE & & & $\begin{array}{c}-0.018 \\
(0.036)\end{array}$ & & & $\begin{array}{l}2.114 \\
(1.47)\end{array}$ \\
\hline THPSE & & & $\begin{array}{c}0.012 \\
(0.021)\end{array}$ & & & $\begin{array}{l}0.843 \\
(1.55)\end{array}$ \\
\hline INF & $\begin{array}{c}-0.03 \text { ** } \\
(0.18)\end{array}$ & $\begin{array}{c}-0.02 * * * \\
(0.14)\end{array}$ & $\begin{array}{c}-0.05^{*} \\
(0.84)\end{array}$ & $\begin{array}{l}0.04^{* *} \\
(0.27)\end{array}$ & $\begin{array}{c}0.07^{* * *} \\
(0.62)\end{array}$ & $\begin{array}{l}0.03 * * \\
(0.54)\end{array}$ \\
\hline $\mathrm{R}^{2}$ & 0.068 & 0.562 & 0.034 & 0.049 & 0.042 & 0.022 \\
\hline
\end{tabular}

Note: The sign ${ }^{* *}$ and ${ }^{* *}$ show significance at $5 \%$ and $10 \%$ respectively. Bootstrap Robust standard errors are given in parentheses.

In the above (Table 3), the impact of institutional reforms is observed for economic growth and investment. The economic reforms are divided into categories; big and small economic reforms. The value of the dummy variable of economic reforms is equal to 1 in the years of post-reforms for treated economies only. The economies that have not economic reforms or having reforms much earlier are treated as control group [41]. The estimated coefficients express the average performances of the treated group relative to the control group and reveal that economic institutional reforms are significant for economic growth, while pre and post reforms in three years are not significant. It is evident that economic institutional reforms are a source to attract investment and countries grow faster on average. The countries with small reforms grow faster as compared with countries having big reforms but these big reforms attract more investment [39,40]. Moreover, more than 3 years of economic reforms are mandatory to affect the economic growth and investment because pre and post three years' reforms are not significantly different from each other. Small 
economic reforms moderate the government interference enhancing the level of growth and investment. Therefore, big economic institutional reforms have a strong correlation with growth and investment [42]. The impact of pre and post-economic reforms on growth and investment is determined and found that economic-institutional reforms help to sustain the investment level only when it continues to improve for more than three years [43]. If countries move continuously with economic reforms then sustainable economic growth is expected and attraction of investment, which ultimately leads to enhanced industrial output, increased foreign investment, and more production opportunities. The countries starting with small economic reforms and do not move towards big economic reforms remain unable to get higher economic growth and even turn to negative after some time [44]. On the other side, big economic reforms refer to high economic freedom, boosting and sustaining economic growth at a faster pace, and attracting more investment. The findings of the study are consistent with $[28,29]$. In the same way, the level of investment will increase when reforms continue to occur beyond three years because if economic reforms last longer for three years only then it will never attract more investment over time, and it may be negative after three years. The studies like [26,29,35,44-46] highlight the positive impact of economic institutions on growth and investment. It is evident from empirical analysis that inflation in developing countries is hurting the economic growth while it is fruitful for investment in these countries. Moreover, inflation is not a source to bring economic or political institutional reforms.

The estimated outcomes of the models in Table 4 show that political institutional reforms have a negative impact on both economic variables. It can be found that three years before the political reforms had a negative effect on economic growth and investment [40]. It reflects that political institutional reforms are initiated by crisis and reforms start when the investment level in an economy is 6.48 points less than the usual investment. The past three years of political institutional reforms have not had a significant impact on economic growth, but after three years of political reforms and beyond four years, growth and investments get positive patterns. The political reforms have not an immediate effect on the economies but it is a slow and gradual process to have their positive impacts on the economies $[29,30]$. The political reforms require a long time to affect economic growth and investment in a positive way. The political reforms in any economy create uncertainty in the society in the beginning but when trust of people is restored in political institutions then investors have more attraction to invest in a favorable environment. This investment increases economic growth at a faster pace and the economy is set on the path of sustainable development [47]. The empirical analysis highlights that the fruitful impact of political reforms is ripped after three years of implementation so confidence of investors and businessmen is restored and economic activities are accelerated. Many studies [24,32,36,37,48] explain that economic activities increase the level of exports in democratic countries. The prosperity of the export sector leads to the development of the financial sector of the country. All these sectors prove themselves a source of sustainable and growing economy. It is explained that countries experiencing political reforms have a positive impact on growth and investment within a decade. Such changes can occur with a well-planned government structure that revolutionizes the economy with an efficient political-institutional environment. According to $[49,50]$, democratic economies are associated with positive macroeconomic stability.

In the perspective of the interaction between political reforms and economic reforms, estimations present some interesting findings. The table in the Appendix A reflects the interaction impact of both types of institutional reforms. It can be found that one type of reform does not lead to other types of reforms. So the findings of the study reveal that political institutional reforms do not stimulate the economic institutional reforms and vice versa. It could be noted that the possibility that both reforms are stimulated by the same factors. The study [40] determined the impact of economic-institutional reforms on political-institutional reforms and vice versa, but findings were similar to this study. Weak institutional reforms do not help the political environment positively if it remains only for three years. The same findings in many studies $[27,34,40,41,51]$ are observed. 
Table 4. Impact of Political Reforms on Growth and Investment.

\begin{tabular}{ccccc}
\hline & \multicolumn{2}{c}{ Growth } & \multicolumn{2}{c}{ Investment } \\
\hline Variables & Model 1 & Model 2 & Model 4 & Model 5 \\
\hline \multirow{2}{*}{ Constant } & $-1.27^{* * *}$ & $-1.89^{* * *}$ & $-3.12^{*}$ & $-2.47^{* *}$ \\
& $(0.538)$ & $(1.241)$ & $(1.527)$ & $(1.237)$ \\
PRef & $-0.151^{* *}$ & & $-1.624^{* *}$ & \\
& $(0.048)$ & & $(1.146)$ & $-6.482^{* *}$ \\
THPRP & & -0.039 & & $(1.267)$ \\
& & $(0.047)$ & & $3.241^{*}$ \\
THPSP & 0.049 & & $0.841)$ \\
& & $(0.084)$ & & $1.725^{* *}$ \\
FRBYP & & $0.326^{* *}$ & & $(0.921)$ \\
INF & $(0.051)$ & 1.47 & $0.51 * *$ \\
R-squared & $(1.27)$ & $-0.74^{* * *}$ & $(1.21)$ & $(2.44)$ \\
\end{tabular}

Note: The sign ${ }^{* *}$ and ${ }^{* * *}$ show significance at $5 \%$ and $10 \%$ respectively. Bootstrap Robust standard errors are given in parentheses.

Table 5. Impact of Political and Economic Reforms on Macroeconomic Variables.

\begin{tabular}{ccc}
\hline & Growth & Investment \\
\hline \multirow{2}{*}{ Constant } & $0.728^{* * *}$ & $1.284^{* * *}$ \\
& $(0.428)$ & $(1.243)$ \\
ERef & $0.276^{* * *}$ & $0.371^{* * *}$ \\
& $(0.359)$ & $(0.527)$ \\
PRef & $-0.211^{* * *}$ & $-2.372^{* * *}$ \\
& $(0.216)$ & $(1.337)$ \\
ECPL & -0.005 & $6.341^{* *}$ \\
PLEC & $(0.018)$ & $(0.579)$ \\
& 0.093 & $-4.357^{* *}$ \\
INF & $(0.029)$ & $(2.951)$ \\
R-squared & $-0.21^{* * *}$ & $0.46^{* *}$ \\
& $(1.841)$ & $(2.57)$ \\
\end{tabular}

Note: ${ }^{* *}$ and ${ }^{* * *}$ show significance at $5 \%$ and $10 \%$ respectively. Bootstrap Robust standard errors are given in parentheses.

The findings of the above Table 5 shed some light upon the sequence of institutional reforms affecting investment and economic growth. It is evident that economies with economic-institutional reforms after political-institutional reforms have lower levels of investment while economies starting with economic institutional reforms before political reforms have higher levels of investment on average. Secondly, economies embarking only on political reforms without economic institutional reforms grow slower, and investment is less while countries focusing only on economic institutional reforms have higher growth and investment. Economic reforms stabilize the financial markets also, which means if the economy starts with economic reforms before political reforms, it will grow more rapidly. Similarly, if countries start with political-institutional reforms, then macroeconomic variables will remain poor and lead to slower economic growth. The studies $[29,37,41,52,53]$ got similar results with this study, and they concluded that the sequence of reforms is very important for the growth and sustainability of the economies. Countries that start up with economic-institutional reforms first then political reforms lead to better macroeconomic indicators [42]. It is argued that economic reforms encourage economic liberalization and investment when states become democratic. 


\section{Conclusions}

Institutional quality has got substantial attention since the evolution of new institutional economics for its active role at the macroeconomic level. Numerous studies explored the relationship between institutional quality and economic growth but the impact of institutional reforms is not fully identified. This study carried out the theoretical and empirical analysis to describe the different dimensions of institutional reforms.

Multiple problems affecting developing economies are not only due to technical failings but due to institutional and political failings [31,32,43]. Modern challenges are stressing the effective implementation of institutional reforms nowadays. It is clear that serious political and economic-institutional reforms in developing economies are beneficial for everyone irrespective of political orientation and views. External and internal pressures, requirements of development partners, changes in global terms of trade are triggering institutional and political reforms. These reforms provide a less risky and fair profit return climate to attract investors enhancing the economic growth of these economies. The investors intend to spend money in such territory where there is less risk to lose their money.

It is interesting to know that institutional reforms are necessary either at the growth stage or the crisis stage. Reforms are a part of crisis management if the country is at the stage of crisis or sometimes a saving tool. On the other hand, if the country is at a growth stage then reforms require plentiful resources so growth may be slowed down. Moreover, the countries are focusing, either, on political-institutional reforms or economic-institutional reforms but the sequence of reforms is a question that needs to be answered.

This study is an attempt to answer all the above questions. The study explained the meaning of institutional reforms and impact of political and economic-institutional reforms on macro-economy of developing economies. This study applied a difference in difference estimation technique to evaluate the effects of institutional reforms on economic growth and investment. The reforms are measured through economic and political-institutional reforms and data are taken for 122 developing economies covering the period from 1996 to 2019.

Many developing countries urge to make or strengthen both types of institutional reforms, political and economic; while some economies focus only on one type of reforms. The findings of the study express that countries consider the gradual economic reforms are growing at a faster pace as compared with the default period. The default period is the time before the reforms or absence of reforms. According to empirical analysis, considerable findings are related to the sequence of reforms. The pattern of reforms varies from country to country. Some countries started with political then economic reforms but several countries in the sample started both types of reforms at the same time. Political-institutional reforms are preceded by economic crises like lower economic growth and decreased investment level as compared with the average rate of investment and economic growth. Usually, countries focusing on political reforms do not overcome the crises immediately that trigger the reforms. In addition, the study could not gain any empirical evidence that either reforms trigger other types of reforms.

First, we address the impact of economic-institutional reforms on selected macroeconomic variables. It is found that there is a sharp increase in growth and investment when economies experience strong economic institutions. The liberalization of economic institutions is associated with higher economic growth attracting more investment. Secondly, the study analyzed the impact of political-institutional reform on the same macroeconomic variables to find out the difference between the effect of economic and political-institutional reforms to make an important decision regarding macroeconomy. However, political liberalization has a positive and significant impact on economic growth. In other words, estimations describe that political-institutional reforms lead to an increase in the level of economic growth, but it is not statistically appropriate with the level of investment. The reason for this negative relation is that the political instability, unstable judiciary environment, and a lack of government effectiveness create an uncertain environment for the investors to 
make new investments. It is observed that politically unstable economies are less trusted because the majority of the groups dominate the law and judiciary system, and authorities are unable to check the credibility and accountability of these political leaders. In such a case, economic-institutional reforms become essential with effective policy implications to ensure the protection of property rights.

Thirdly, the feedback effect of both reforms on each other is also examined in the study. It is found that economic reforms are not correlated with political-institutional reforms, which means each type of reform does not stimulate other. It is also a question of concern about the sequence of institutional reforms. The empirical evidence reveals that sequence of institutional reforms has not any impact on economic growth but this sequence plays its role for investment level in a country. The findings of the study express that economic-institutional reform before political reforms increase the level of investment, while countries starting with political reforms have lower levels of investment. In the same way, countries embarking only on political reforms without economic reforms have lower levels of investment and economic growth.

Historically, many economies take the first step to make their political environment better then, other institutions matter for them. This study steps out to analyze what countries should choose first. This study finds out that economies experiencing economic liberalization first seem to boost economic growth and investment at a faster pace because it gives more confidence to investors and businessmen and the business environment is more competitive for economic potential.

It can be concluded that a long period is required to take the positive effects of political reforms on investment and growth. The systematic and gradual reforms are necessary to rip their fruit. The findings of the study suggest that it is wise to start with economicinstitutional reforms before political reforms. The countries focusing on political reforms without economic reforms may not attain higher levels of investment and growth.

The findings of the study reveal that many countries in the sample started with political reforms, which led to a fall in economic growth. The economies chose economic reforms first, achieved a strong and efficient institutional structure along with high economic growth and investments. Policymakers should keep in view this pattern while formulating and implementing domestic and international economic policies. Economic-institutional reforms should be strong enough to protect property rights that enlarge the environment of trust in the society and provide revolutionary growth in the economy. The political reforms may be carried out after the successful implementation of economic reforms. Now economies may have many resources to overcome the negative consequences resulting from political reforms. So, policymakers should choose the economic reforms first as a policy option. It is also vivid that both types of reforms cannot be applied simultaneously.

The literature may be extended by analyzing the impact of reforms in financial institutions on macroeconomic variables. These reforms may be compared with reforms of developed countries. There is hardly any study available on this topic. Besides, the impact of informal institutions can be explored on macroeconomic indicators. Moreover, this study used a limited sample and period due to the availability of data so it may be extended.

Author Contributions: Conceptualization-original draft preparation, J.Z.; methodology-data curation, G.R.M.; writing-review and editing, M.A.A.; literature review, S.M.Z. All authors have read and agreed to the published version of the manuscript.

Funding: This research received no external funding.

Data Availability Statement: The data is available on official websites of The Heritage Foundation, Centre for Systemic Peace and World Bank.

Conflicts of Interest: The authors declare no conflict of interest. 


\section{Appendix A. List of Sample Countries}

Afghanistan, Albania, Algeria, Andorra, Angola, Antigua and Barbuda, Argentina, Armenia, Azerbaijan, Bangladesh, Barbados, Belarus, Belize, Benin, Bhutan, Bolivia, Bosnia and Herzegovina, Botswana, Bulgaria, Burkina Faso, Burundi, Cabo Verde, Cambodia, Cameroon, Central African Republic, Chad, Chile, China, Colombia, Comoros, Costa Rica, Croatia, Cuba, Cyprus, Congo, Dominica, Dominican Republic, Ecuador, Egypt, El Salvador, Eritrea, Estonia, Ethiopia, Fiji, Gabon, Georgia, Ghana, Grenada, Guatemala, Guinea, Guyana, Haiti, Honduras, Iceland, India, Indonesia, Iran, Iraq, Jordan, Kazakhstan, Kenya, Kyrgyzstan, Liberia, Libya, Malawi, Malaysia, Maldives, Mali, Malta, Mauritania, Mauritius, Mexico, Moldova, Monaco, Mongolia, Morocco, Mozambique, Myanmar, Namibia, Nepal, Nigeria, North Korea, Pakistan, Palau, Panama, Paraguay, Philippines, Poland, Portugal, Romania, Rwanda, Senegal, Serbia, Somalia, South Korea, South Sudan, Sri Lanka, St. Kitts and Nevis, St. Lucia, St. Vincent and the Grenadines, Sudan, Suriname, Syria, Tajikistan, Tanzania, Thailand, The Gambia, Timor-Leste, Togo, Tonga, Tunisia, Turkey, Turkmenistan, Tuvalu, Uganda, Ukraine, Uruguay, Uzbekistan, Vanuatu, Venezuela, Vietnam, Yemen, Zambia.

Table A1. Interaction between political and economic reforms.

\begin{tabular}{ccccc}
\hline Variables & \multicolumn{2}{c}{ Economic Reforms } & \multicolumn{2}{c}{ Political Reforms } \\
\hline \multirow{2}{*}{ Constant } & 2.327 & 3.134 & 4.284 & 6.729 \\
& $(0457)$ & $(1.289)$ & $(2.492)$ & $(5.283)$ \\
PRef & -0.138 & & & \\
THPRP & $(0.279)$ & -0.217 & & \\
THPSP & & $(0.341)$ & & \\
FRBYP & & -0.211 & & \\
& & $(0.189)$ & & \\
SERef & & 0.317 & -0.0342 & -0.284 \\
& & $(0.362)$ & $(0.0117)$ & $(0.315)$ \\
THPRE & & & & -0.038 \\
& & & & 1.34 \\
THPSE & & & 0.89 & $(0.89)$ \\
& & & $(1.27)$ & 0.044 \\
\hline INF & 0.34 & $(2.81)$ & 0.031 & \\
R-squared & $(1.84)$ & 0.044 & &
\end{tabular}

Note: Bootstrap Robust standard errors are given in parentheses.

\section{References}

1. Rodrik, D.; Subramanian, A.; Trebbi, F. Institutions Rule: The Primacy of Institutions over Geography and Integration in Economic Development. J. Econ. Growth 2004, 9, 131-165. [CrossRef]

2. Acemoglu, D.; Johnson, S.; Robinson, J. The Colonial Origins of Comparative Development: An Empirical Investigation. Am. Econ. Rev. 2001, 91, 1369-1401. [CrossRef]

3. Acemoglu, D.; Johnson, S.; Robinson, J. Reversal of Fortune: Geography and Institutions in the Making of the Modern World Income Distribution. Q. J. Econ. 2002, 117, 1231-1294. [CrossRef]

4. Acemoglu, D.; Johnson, S.; Robinson, J.A. Institutions as the Fundamental Cause of Long-Run Growth. Handb. Econ. Growth 2005, 1A, 386-472.

5. Hall, R.E.; Jones, C.I. Why Do Some Countries Produce So Much More Output per Worker than Others? Q. J. Econ. 1999, 114, 83-116. [CrossRef]

6. Knack, S.; Keefer, P. Institutions and Economic Performance: Cross-Country Tests using Alternative Institutional Measures. Econ. Politics 1995, 7, 207-227. [CrossRef]

7. Mauro, P. Corruption and Growth. Q. J. Econ. 1995, 110, 681-712. [CrossRef]

8. North, D.C. Institutional Change and Economic Performance; Cambridge University Press: Cambridge, UK, 1995.

9. North, D.C. Institutions. J. Econ. Perspect. 1991, 5, 97-112. [CrossRef] 
10. North, D.C.; Weingast, B.R. Constitutions and Commitment: The Evolution of Institutional Governing Public Choice in Seventeenth Century England. J. Econ. Hist. 1989, 49, 803-832. [CrossRef]

11. Huang, Y. Political Institutions and Financial Development: An Empirical Study. World Dev. 2010, 38, 1667-1677. [CrossRef]

12. Haggard, S. Institutions and Growth in East Asia. SCID 2004, 38, 58-81. [CrossRef]

13. Glaeser, L.E. Do Institutions Cause Growth? J. Econ. Growth 2004, 9, 271-303. [CrossRef]

14. Madni, G.R.; Anwar, A. Meditation for Institutional Quality to Combat Income Inequality through Financial Development. Int. J. Financ. Econ. 2020, 26, 2766-2775. [CrossRef]

15. Alesina, A.; Perotti, R. The Political Economy of Growth: A Critical Survey of the Recent Literature. World Bank Econ. Rev. 1994, 8, 351-371. [CrossRef]

16. Jong-a-Pin, R.; de Haan, J. Political Regime Change, Economic Reform and Growth Accelerations; CESIFO Working Paper, No. 1905; CESIFO: München, Germany, 2007.

17. Giavazzi, F.; Tabellini, G. Economic and Political Liberalizations. J. Monet. Econ. 2005, 52, 1297-1330. [CrossRef]

18. Persson, T. Forms of Democracy, Policy and Economic Development, Institute for International Economic Studies; Stockholm University Working Paper, No. 050131; Stockholm University: Stockholm, Sweden, 2005.

19. Reuveny, R.; Li, O. Economic Openness, Democracy and Income Inequality. Comp. Political Stud. 2003, 36, 575-601. [CrossRef]

20. Alesina, A.; Zhuravskaya, E. Segregation and the Quality of Government in a Cross Section of Countries. Am. Econ. Rev. 2010, 101, 1872-1911. [CrossRef]

21. Roll, R.; Talbott, J. Political and Economic Freedoms and Prosperity. J. Democr. 2003, 14, 75-89. [CrossRef]

22. Wacziarg, R.; Welch K, H. Trade Liberalization and Growth: New Evidence; NBER Working Paper No. 10152; NBER: Cambridge, MA, USA, 2003.

23. Przeworski, A.; Limongi, F. Democracy and Development: Political Regimes and Well-Being in the World, 1950-1990; Cambridge University Press: Cambridge, UK, 2000.

24. Barro, R. Democracy and Growth. J. Econ. Growth 1996, 1, 1-27. [CrossRef]

25. Madni, G.R. Probing institutional quality through ethnic diversity, income inequality and public spending. Soc. Indic. Res. 2019, 142, 581-595. [CrossRef]

26. Sachs, J.; Warner, A. Economic Reform and the Process of Global Integration. Brook. Pap. Econ. Act. 1995, 1, 1-95. [CrossRef]

27. Barro, R. Economic growth in a cross section of countries. Q. J. Econ. 1991, 106, 407-443. [CrossRef]

28. Caldwell, T.M. The Institutional Foundations of Democratic Government: A Comparison of Presidential and Parliamentary. J. Inst. Theor. Econ. 1994, 171-195.

29. Knack, S. Institutions and the Convergence Hypothesis: The Cross National Evidence. Public Choice. 1996, 87, 207-228. [CrossRef]

30. Kaufmann, D.; Kraay, A.; Zoido, P. Governance Matters; World Bank policy research working paper no 2196; World Bank: Washington, DC, USA, 1999.

31. Engerman, K.L. Institution, Factor Endowment and Path of Development. J. Econ. Prospect. 2000, 14, $217-232$.

32. Acemoglu, D.; Johnson, S.; Robinson, J.A.; Thaicharoen. Institutional causes, macroeconomic symptoms: Volatility, crises and growth. J. Monet. Econ. 2003, 50, 49-123. [CrossRef]

33. Siourounis, E.P. Economic and Social Factors Driving the Third Wars of Democratization. J. Comp. Econ. 2008, 36, 365-387.

34. Buterin, V.; Scissors, M.; Buterin, D. Macroeconomic model of institutional reforms' influence on economic growth of the new EU members and the Republic of Croatia. Econ. Res. 2017, 30, 1572-1593. [CrossRef]

35. Khan, M.A.; Kong, D.; Xiang, J.; Zhang, J. Impact of institutional quality on financial development: Cross-country evidence based on emerging and growth-leading economies. Emerg. Mark. Financ. Trade 2020, 56, 3829-3845. [CrossRef]

36. Snow, J. On the Mode of Communication of Cholera; OCLC: 14550757; John Churchill: London, UK, 1849.

37. Snow, J. On the Mode of Communication of Cholera, 2nd ed.; John Churchill: London, UK, 1855; Available online: http:/ / archive. org/details/b28985266 (accessed on 9 September 2020).

38. Wing, K.S. Designing difference in difference studies. Annual Rev. Public Health 2018, 453-457. [CrossRef]

39. Giavazzi, F.; Schiantarelli, F.; Serafinelli, M. Attitudes, Policies, and Work. J. Eur. Econ. Assoc. 2013, 11, 1256-1289. [CrossRef]

40. Kilish, A.H. Institutional reforms and Economic Outcome in Africa; African Development Bank Group: Abidjan, Côte d'Ivoire, 2017.

41. Dixit, A. Governance institutions and economic activity. Am. Econ. Rev. 2009, 99, 5-24. [CrossRef]

42. Torstensson, J. Property rights and economic growth: An empirical study. Kyklos 1994, 47, 231-247. [CrossRef]

43. Crawford, V.; Sobel, J. Strategic Information Transmission. Econometrica 1982, 50, 1431-1451. [CrossRef]

44. Blundell, R.; McCurdy, T. Labor Supply: A Review of Alternative Approaches. In Handbook of Labor Economics; Ashenfelter, O., Card, D., Eds.; Elsevier: Amsterdam, The Netherlands, 2000; Volume 3.

45. Persson, T.; Tabellini, G. The Economic Effects of Constitutions; MIT Press: Cambridge, MA, USA, 2003.

46. Madni, G.R.; Chaudhary, M.A. Economic growth in context of institutions and fiscal policy. Pak. Econ. Soc. Rev. 2017, 55, 79-98.

47. Ulman, S.R.; Bujancă, G.V. The corruption influence on the macroeconomic environment. Empirical analysis on countries development stages. Procedia Econ. Financ. 2014, 16, 427-437. [CrossRef]

48. Alesina, A.; Hems, L.C.; Chinnock, K. The political economy of high and low growth. In Annual World Bank Conference on Development Economics 1998; Pleskovic, B., Stiglitz, J.E., Eds.; World Bank Group: Washington, DC, USA, 1998 ; pp. $217-237$.

49. Alchian, A.; Demsetz, H. The Property Right Paradigm. J. Econ. Hist. 1973, 33, 16-27. [CrossRef] 
50. Chong, A.; Calderon, C. Causality and feedback between institutional measures and economic growth. Econ. Politics 2000, $12,69-81$. [CrossRef]

51. Fors, H.C.; Olsson, O. Endogenous institutional change after independence. Eur. Econ. Rev. 2007, 51, 1896-1921. [CrossRef]

52. Anwar, A.; Ahmad, N.; Madni, G.R. Industrialization, freight transport and environmental quality: Evidence from belt and road initiative economies. Environ. Sci. Poll Res. 2020, 27, 7053-7070. [CrossRef] [PubMed]

53. Grafton, R.Q.; Knowles, S. Social capital and national performance: A cross-country analysis. J. Environ. Dev. 2004, 13, 336-370. [CrossRef] 